\title{
Testicular adrenal rest tumor in infertile man with congenital adrenal hyperplasia: case report and literature review
}

\author{
Tumor testicular de remanescente adrenal em homem infértil com hiperplasia \\ adrenal congênita: relato de caso e revisão de literatura
}

\author{
Giovanni Scala Marchini', Marcello Cocuzza", Rodrigo Pagani", Fábio César Torricelli', Jorge Hallak", Miguel Srougi"l' \\ Department of Urology, Hospital das Clínicas (HC), Faculdade de Medicina da Universidade de São Paulo (FMUSP), São Paulo, Brazil
}

\begin{abstract}
'Resident, Department of Urology, Hospital das Clínicas (HC), Faculdade de Medicina da Universidade de São Paulo (FMUSP), São Paulo, Brazil.

"MD. Attending physician. Department of Urology, Hospital das Clínicas (HC), Faculdade de Medicina da Universidade de São Paulo (FMUSP), São Paulo, Brazil.

"'MD. Professor and Head, Department of Urology, Hospital das Clínicas (HC), Faculdade de Medicina da Universidade de São Paulo (FMUSP), São Paulo, Brazil.
\end{abstract}

\section{KEY WORDS:}

Adrenal hyperplasia, congenital.

Adrenal rest tumor.

Infertility.

Testis.

Microsurgery.

\section{PALAVRAS-CHAVE:}

Hiperplasia supra-renal congênita.

Tumor de resto supra-renal.

Infertilidade.

Testículo.

Microcirurgia.

\begin{abstract}
CONTEXT: Synthesis of cortisol and aldosterone is impaired in patients with congenital adrenal hyperplasia (CAH) because of 21-hydroxylase deficiency. Men with CAH have low fertility rates compared with the normal population, and this is related to testicular adrenal rest tumors. Findings of azoospermia in combination with a testicular tumor on ultrasound are likely to have a mechanical cause, especially when in the testicular mediastinum. The preferred treatment method consists of intensive corticoid therapy. However, when the tumor is unresponsive to steroid therapy, surgical treatment should be considered.

CASE REPORT: We present the case of a male patient with CAH due to 21-hydroxylase deficiency who presented a testicular tumor and azoospermia. Treatment with low daily corticoid doses had previously been started by an endocrinologist, but after 12 months, no significant change in sperm count was found. Although the adrenocorticotrophic hormone and 17-hydroxyprogesterone levels returned to normal values, the follicle-stimulating hormone (FSH), luteinizing hormone and testosterone levels remained unchanged. Ultrasound examination confirmed that the testicles were small and heterogenous bilaterally, and revealed a mosaic area at the projection of the testis network bilaterally. Magnetic resonance imaging confirmed the finding. Testicular biopsy revealed the presence of preserved spermatogenesis and spermiogenesis in $20 \%$ of the seminiferous tubules in the right testicle. The patient underwent testis-sparing tumor resection. After 12 months of follow-up, there was no tumor recurrence but the patient still presented azoospermia and joined an intracytoplasmic sperm injection program.
\end{abstract}

\section{RESUMO}

CONTEXTO: Pacientes com hiperplasia adrenal congênita (HAC) por deficiência da 21-hidroxilase podem ter a síntese de cortisol e de aldosterona prejudicada. Homens com HAC têm baixas taxas de fertilidade em comparação com a população normal, e isso está relacionado a tumores testiculares de remanescente adrenal. A associação de azoospermia e tumor testicular sugere uma causa mecânica, principalmente quando o tumor é encontrado no mediastino testicular. O método preferencial de tratamento consiste na corticoterapia intensa. No entanto, quando o tumor não é responsivo à terapia com esteroides, o tratamento cirúrgico deve ser considerado.

RELATO DE CASO: Apresentamos o caso de um paciente do sexo masculino com HAC por deficiência da 21-hidroxilase, portador de tumor testicular e azoospermia. Em consulta prévia com endocrinologista, o paciente começou tratamento com baixas doses diárias de corticoide, porém, após 12 meses de tratamento, não houve mudança significativa no espermograma. Embora os níveis de hormônio adrenocortitrófico e 17-hidroxiprogesterona tenham se normalizado, os níveis séricos de hormônio folículoestimulante, hormônio luteinizante e testosterona não se alteraram. Exame ultrassonográfico confirmou testículos bilateralmente diminuídos e heterogêneos, além de área em mosaico na projeção da rede testis bilateralmente. Ressonância nuclear magnética confirmou o achado. Biópsia testicular revelou espermatogênese e espermiogênese preservadas em 20\% dos túbulos seminíferos no testículo direito. O paciente foi submetido a cirurgia poupadora testicular, com ressecção tumoral. Após 12 meses de acompanhamento, não houve recorrência tumoral, mas o paciente ainda apresentava azoospermia, sendo integrado no programa de injeção intracitoplasmática de espermatozoides. 


\section{INTRODUCTION}

Synthesis of cortisol and sometimes of aldosterone is impaired in patients with congenital adrenal hyperplasia $(\mathrm{CAH})$ because of 21-hydroxylase deficiency. Men with CAH have low fertility rates compared with the normal population, and this is related to testicular adrenal rest tumors (TART). ${ }^{1,2}$ Development of the primitive adrenal cortex occurs close to the gonads and TART is considered to be an aberrant adrenal tissue that has descended with the testes. ${ }^{3}$ Pretumor development and growth of these cells is assumed to be adrenocorticotrophic hormone (ACTH) dependent, and undertreatment may play an important role in tumor development. However, intensive glucocorticoid treatment is not always successful in reducing tumor size, and such tumors can be found in as many as $95 \%$ of CAH patients. ${ }^{4-10}$ These tumors were first described by Wilkins et al. in 1940 and they are almost always present bilaterally. ${ }^{11}$ Even though they have benign features, they may lead to obstruction of the seminiferous tubules and ultimately infertility, because of their location in the testicular mediastinum. ${ }^{12-14} \mathrm{CAH}$ patients not only have anatomical lesions but also have impaired testicular function and hypogonadotropic hypogonadism due to chronic suppression of gonadotropin secretion caused by overproduction of adrenal androgens. ${ }^{5}$ We present the case of a male patient with congenital adrenal hyperplasia due to 21-hydroxylase deficiency who presented a testicular tumor and infertility.

\section{CASE REPORT}

A 39-year-old male patient was referred to our Andrology Division because of primary infertility. He had a past medical history of CAH due to 21-hydroxylase deficiency.

At four years of age, the patient was diagnosed as having the simple virilizing non-salt wasting form of CAH. Treatment with low-dose glucocorticoid ( $0.5 \mathrm{mg}$ of dexamethasone) was started and he did not need any mineralocorticoid replacement. The patient evolved normally until 22 years of age, when he abandoned his treatment and was lost from follow-up consultations.
He sought medical counseling fifteen years later because of infertility. He was healthy and not taking any medications at that time. He and his wife failed to achieve pregnancy for two years. She did not have any previous offspring, and all possible causes of female infertility were ruled out.

At physical examination, he was seen to have small stature (height: $1.68 \mathrm{~m}$; weight: $78 \mathrm{~kg}$; body mass index: $27.6 \mathrm{~kg} / \mathrm{m}^{2}$ ) and small topically softened testicles compatible with testicular atrophy. Semen analyses revealed azoospermia. Serum hormonal screening showed increased levels of follicle-stimulating hormone (FSH) and luteinizing hormone (LH) and low levels of testosterone, albeit within the normal range, thus suggesting testicular failure. The ACTH and 17-hydroxyprogesterone (17-OHP) levels were high, while the levels of other hormones were within the normal range. Treatment with low-dose daily glucocorticoid therapy ( $0.5 \mathrm{mg}$ of dexamethasone) had been started by an endocrinologist before our first visit, but after twelve months no significant change in sperm count was found. Although the ACTH and 17-OHP levels returned to normal values, the FSH, $\mathrm{LH}$ and testosterone levels showed no great improvement (Table 1).

Testicular ultrasound examination confirmed that the testicles were small and heterogenous bilaterally (right: $9.1 \mathrm{ml}$; left: 9.3 $\mathrm{ml})$. It also revealed the presence of a hyperechogenic hypervascularized tumor mosaic area of $1.5 \times 1.5$ centimeters at the projection of the testis network, in both testicles, thereby suggesting the presence of duct occlusion at this point. Further evaluation using magnetic resonance image (MRI) revealed T2-weighted low-sign bilateral solid elongated serpiginous lesions in the testicular mediastinum, for which adrenal rest tumor was a differential diagnosis (Figures 1 and 2). In order to distinguish testicular failure from obstructive azoospermia, the patient underwent bilateral testicular biopsy. This revealed preserved spermatogenesis and spermiogenesis in $20 \%$ of the seminiferous tubules in the right testicle. It also revealed left testicular atrophy characterized by germ cell hypoplasia and basal membrane thickening.

Table 1. Hormone levels before and after treatment with glucocorticoid

\begin{tabular}{|c|c|c|c|c|}
\hline Serum hormone & Before treatment & After 6 months of dexamethasone & After 12 months of dexamethasone & Normal range \\
\hline FSH & $27 \mathrm{IU} / \mathrm{I}$ & $34 \mathrm{IU} / \mathrm{I}$ & $36.1 \mathrm{IU} / \mathrm{I}$ & $<10.5 \mathrm{IU} / \mathrm{I}$ \\
\hline $\mathrm{LH}$ & $30.9 \mathrm{IU} / \mathrm{I}$ & $18.2 \mathrm{IU} / \mathrm{I}$ & $27.5 \mathrm{IU} / \mathrm{I}$ & $1.0-8.4 \mathrm{IU} / \mathrm{I}$ \\
\hline ACTH & $827 \mathrm{pg} / \mathrm{ml}$ & $38 \mathrm{pg} / \mathrm{ml}$ & $44 \mathrm{pg} / \mathrm{ml}$ & $<46 \mathrm{pg} / \mathrm{ml}$ \\
\hline Free testosterone & $170 \mathrm{pmol} / \mathrm{ml}$ & $109 \mathrm{pmol} / \mathrm{ml}$ & $199 \mathrm{pmol} / \mathrm{l}$ & $131-640 \mathrm{pmol} / \mathrm{l}$ \\
\hline Androstenedione & $4.7 \mathrm{ng} / \mathrm{ml}$ & $1.3 \mathrm{ng} / \mathrm{ml}$ & $<0.3 \mathrm{ng} / \mathrm{ml}$ & $0.3-4.3 \mathrm{ng} / \mathrm{ml}$ \\
\hline Renin activity & $2.3 \mathrm{ng} / \mathrm{ml} / \mathrm{h}$ & $17.7 \mathrm{ng} / \mathrm{ml} / \mathrm{h}$ & $4.3 \mathrm{ng} / \mathrm{ml} / \mathrm{h}$ & $1.5-5.7 \mathrm{ng} / \mathrm{ml} / \mathrm{h}$ \\
\hline SHBG & $46 \mathrm{nmol} / \mathrm{ml}$ & $65 \mathrm{nmol} / \mathrm{ml}$ & $55 \mathrm{nmol} / \mathrm{l}$ & $12-75 \mathrm{nmol} / \mathrm{ml}$ \\
\hline
\end{tabular}

$\mathrm{FSH}$ = follicle-stimulating hormone; $\mathrm{LH}=$ luteinizing hormone; $\mathrm{ACTH}=$ adrenocorticotrophic hormone; $17-\mathrm{OHP}=17$-hydroxyprogesterone; $\mathrm{SHBG}=$ sex hormone-binding globulin. 
The patient underwent testis-sparing tumor resection (Figure 3). Bilateral inguinal incisions were made to access the testis and the tumor masses were microdissected using ultrasound guidance (Figure 4). The patient's hospital stay was uneventful. After twelve months of follow-up, ultrasound showed that there was no evidence of tumor recurrence, but the patient still presented azoospermia. He and his wife agreed to join an intracytoplasmic sperm injection (ICSI) program.

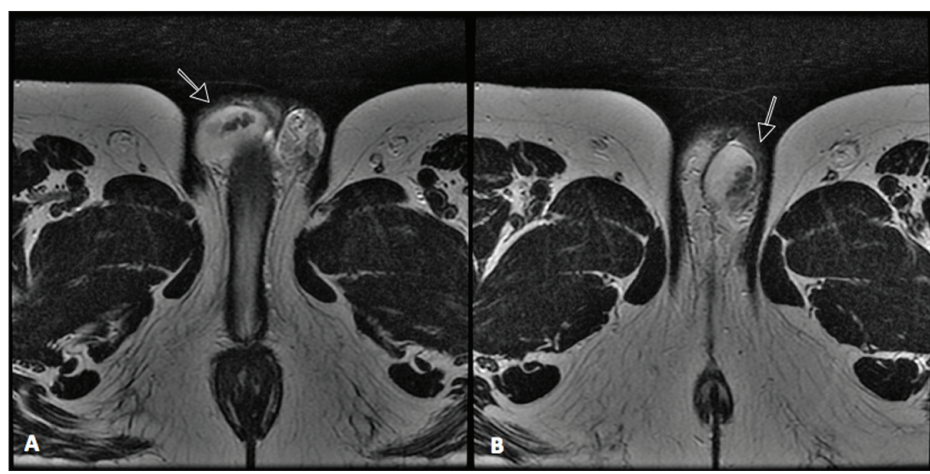

Figure 1. Magnetic resonance imaging (MRI) - Sagittal T2 images revealing low-sign right $(A)$ and left $(B)$ solid elongated serpiginous lesions in the testicular mediastinum (arrows).

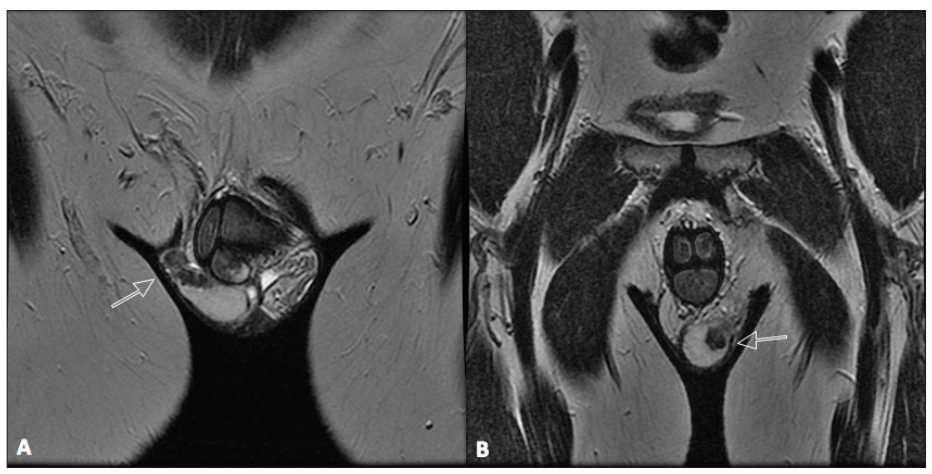

Figure 2. Magnetic resonance imaging (MRI) - Coronal T2 images showing low-sign right (A) and left (B) solid elongated serpiginous lesions in the testicular mediastinum (arrows).

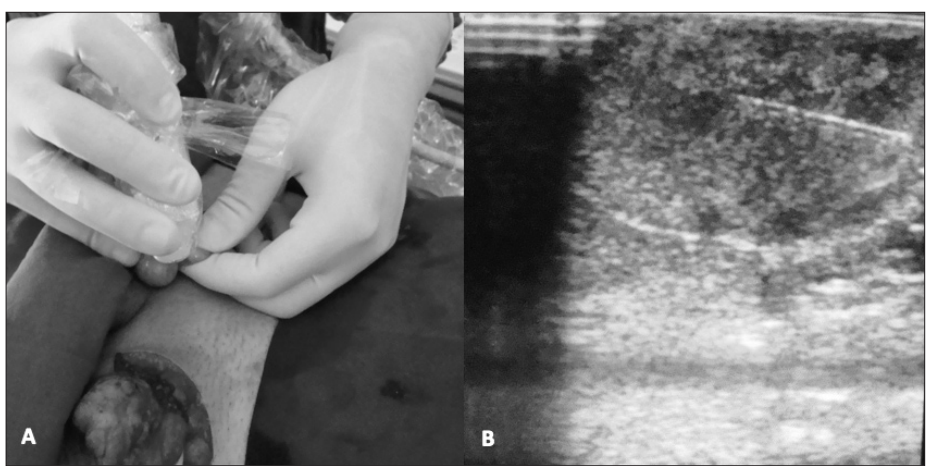

Figure 3. Tumor marking (A) for intraoperative ultrasound examination and needle driving (B).

\section{DISCUSSION}

Defective conversion of 17-OHP to 11-deoxycortisol, mediated by 21-hydroxylase (CYP21A2), accounts for more than $90 \%$ of the cases of CAH. ${ }^{15-17}$ Therapy for CYP21A2 deficiency is directed towards providing glucocorticoid in sufficient doses to reduce the excessive corticotropin-releasing hormone ( $\mathrm{CRH}$ ) levels, corticotropin (ACTH) secretion and hyperandrogenemia. ${ }^{18-20}$ Our patient had the simple virilizing non-salt wasting form of $\mathrm{CAH}$, and after he abandoned his successful glucocorticoid treatment, he presented high serum levels of 17-OHP and infertility.

In 1940, Wilkins et al. reported that testicular tumors occurred in male patients with CAH due to CYP21A2 deficiency, known as so-called testicular adrenal rest tumors (TART) ${ }^{11}$ During the embryological period, steroidogenic cells that are destined to become adrenal and gonadal cells derive from neighboring areas of the coelomic epithelium and are morphologically identical. Their separation takes place in the eighth week of gestation and adrenal cortical tissue may adhere to the gonad and descend with the testis along the course of their supply arteries. ${ }^{21-26}$ In CAH patients, it is believed that these cells can persist and proliferate with preservation of adrenallike hormone-producing properties. TARTs are ACTH-dependent and may develop during periods of sustained elevation of plasma ACTH levels or regress when glucocorticoid therapy is instituted or intensified. ${ }^{4,5,27-34}$ However, in several studies, no correlation was found between intensive glucocorticoid therapy control and tumor growth. ${ }^{4,5,8,9,35-37}$ Therefore, other factors may interfere. Claahsen-van der Grinten et al. showed that these tumors contain varying amounts of steroid-producing enzymes and ACTH and angiotensin II (AII) receptors, at least at the messenger RNA (mRNA) level, which is believed to have a strong trophic effect on the adrenal gland. ${ }^{5,38-43}$

Depending on the detection method (palpation or ultrasound), the reported prevalence of TART among CAH patients may range

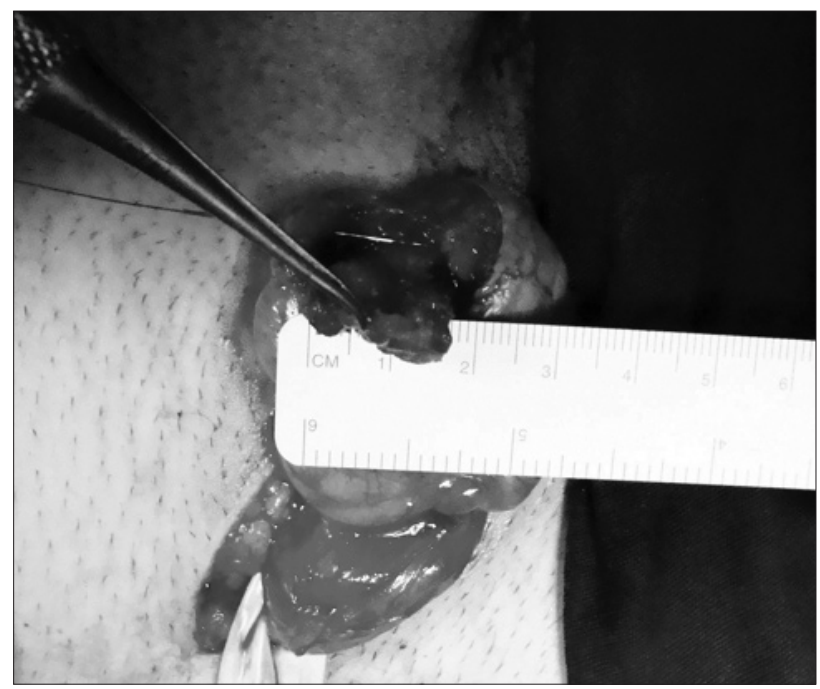

Figure 4. Tumor microdissection and testicular preservation. 
from 0 to $95 \% .{ }^{5,27,43}$ Absence of palpable tumors does not rule out the existence of TART, and ultrasound is the preferred method for evaluating TART because it is as sensitive as MRI but more accessible. $^{2}$ In our case, MRI was necessary to confirm the ultrasound findings. Histologically, electron microscopy shows that TART resembles Leydig cell tumors, with features that are consistent with steroid-secreting cells. However, unlike Leydig cell tumors, they never contain Reinke crystalloids, are often bilateral and may diminish with corticosteroid therapy. ${ }^{44}$

Different mechanisms have been proposed to explain infertility in males with $\mathrm{CAH}^{21,22}$ Stikkelbroeck et al. demonstrated the presence of testicular dysfunction due to decreased plasma testosterone levels in $35 \%$ of the CAH patients that they evaluated, with poor semen quality in $63 \%$ of them. This could be caused mechanically by TART, or by local steroid production. ${ }^{30,45}$ At the hypothalamic-pituitary level, secretion of gonadotropins may be suppressed by high levels of adrenal androgens that are aromatized peripherally or in the central nervous system to estrogens. ${ }^{36,45-48}$ In one study, sperm production was found to be impaired in seven of the eleven patients tested, and three (40\%) even showed azoospermia. In two of the azoospermic patients, the serum FSH levels were increased, thereby indicating primary testicular dysfunction. In the third azoospermic patient, the serum levels of both LH and FSH were undetectably low, thus suggesting the presence of testicular dysfunction due to hypogonadotropism. With these findings, the authors proposed that routine semen analysis should be performed for such patients. When azoospermia is found in combination with a large testicular tumor on ultrasound, it is likely to have a mechanical cause, especially when in the mediastinum. At this location, large tumors can easily compress the testis network and cause obstructive azoospermia, ${ }^{49}$ as found in our patient. The preferred treatment method for testicular adrenal rest tumors and/or impaired spermatogenesis in patients with $\mathrm{CAH}$ is intensive glucocorticoid therapy. This may lead to a decrease in tumor size and improvement of testicular function. ${ }^{28,47,50-52}$ Clomiphene citrate may also be administered, and successful cases have been reported. ${ }^{46,53}$ However, when the tumor is unresponsive to steroid therapy, surgical treatment should be considered, preferably using a testis-sparing procedure. ${ }^{5}$ Recently, Fernandes et al reported a case of a 16-year-old boy who underwent bilateral orchiectomy because of TART that could not be differentiated from a malignant tumor, thus expressing this diagnostic dilemma. ${ }^{54}$

Because of the rarity of TART and its management, we carried out a systematic analysis of the indexed articles published since 1966, in order to provide the best treatment for our patient. We searched using the terms "adrenal rest tumor" and/or "infertility" in the Lilacs (Literatura Latino-Americana e do Caribe em Ciências da Saúde), Embase (Excerpta Medica Database), Medline (Medical Literature Analysis and Retrieval System Online), Scirius and Cochrane Library databases, using DeCS (Descritores em Ciências da Saúde) and MeSH (Medical Subject Headings). Only
10 related references were found in Medline and Scirius, and two in Lilacs (Table 2). Most were descriptive series or case reports. Although proposed by several authors, there is only a single case series addressing surgical management of TART: ${ }^{2}$ Claahsen-van der Grinten et al. evaluated pituitary-gonadal function before and after testis-sparing surgery among CAH patients with TART, and reported that there were no surgical complications and no evidence of residual or recurrent testicular tumor after 22 months. Nonetheless, the semen analysis did not improve after surgery, and persistently low inhibin B levels were found in all patients. The absence of positive effects on testicular function, despite complete removal of the tumors, strongly suggests that irreversible testicular damage preexisted: this was reflected by peritubular fibrosis and tubular hyalinization seen in the testis biopsy specimen that was taken during surgery. ${ }^{2}$ Our patient's semen analyses did not improve with corticosteroid treatment, and the testicular biopsy showed that preserved spermatogenesis and spermiogenesis was present in only $20 \%$ of one side. The other testicle was atrophic. No response was obtained after testicular-sparing surgery. It is clear now that, at this stage, surgery can no longer help to restore testicular function. Cryopreservation of the semen or testicular sperm extraction (TESE) with intrauterine injection (IUI) or intracytoplasmic sperm injection (ICSI) can be offered for these patients, as we did in our case, because the fertility prognosis is uncertain..$^{50}$

\section{CONCLUSION}

The prevalence of testicular tumors in male CAH patients is high, despite adequate treatment. Semen production and testosterone secretion may be impaired, especially when large testicular tumors are present. The diagnosis can be achieved using ultrasound or MRI, and early treatment for TART by means of glucocorticoid should be of primary concern. Testis-sparing surgery is

Table 2. Complete literature database search using the terms "adrenal rest tumor" and "infertility" as medical subject headings (MeSH)

\begin{tabular}{|c|c|c|c|c|}
\hline Database & $\begin{array}{l}\text { Search } \\
\text { strategy }\end{array}$ & \multicolumn{3}{|c|}{ Results } \\
\hline $\begin{array}{l}\text { PubMed } \\
\text { (Medline) }\end{array}$ & $\begin{array}{l}\text { Adrenal rest } \\
\text { tumor (MeSH) } \\
\text { AND Infertility }\end{array}$ & Found: 10 & Related: 10 & $\begin{array}{c}\text { Case reports: } 1 \\
\text { Reviews: } 2 \\
\text { Descriptive series: } 7\end{array}$ \\
\hline Embase & $\begin{array}{l}\text { Adrenal and } \\
\text { rest and tumor }\end{array}$ & Found: 1 & Related: 0 & - \\
\hline Scirius & $\begin{array}{l}\text { Adrenal rest } \\
\text { tumor (MeSH) } \\
\text { AND Infertility }\end{array}$ & Found: 10 & Related: 10 & $\begin{array}{c}\text { Case reports: } 5 \\
\text { Reviews: } 3 \\
\text { Descriptive series: } 2\end{array}$ \\
\hline Lilacs & $\begin{array}{c}\text { Adrenal rest } \\
\text { tumor (MeSH) }\end{array}$ & Found: 5 & Related: 2 & Case reports: 2 \\
\hline Cochrane & $\begin{array}{l}\text { Adrenal and } \\
\text { rest and tumor }\end{array}$ & Found: 2 & Related: 0 & - \\
\hline
\end{tabular}

Lilacs = Literatura Latino-Americana e do Caribe em Ciências da Saúde; Medline = Medical Literature Analysis and Retrieval System Online; MeSH = Medical Subject Headings. 
feasible, but may not result in testicular function improvement. Alternative fertility techniques and genetic counseling should be offered when all methods fail.

\section{REFERENCES}

1. Claahsen-van der Grinten HL, Stikkelbroeck NM, Sweep CG, Hermus AR, Otten BJ. Fertility in patients with congenital adrenal hyperplasia. J Pediatr Endocrinol Metab. 2006;19(5):677-85.

2. Claahsen-van der Grinten HL, Otten BJ, Takahashi S, et al. Testicular adrenal rest tumors in adult males with congenital adrenal hyperplasia: evaluation of pituitary-gonadal function before and after successful testis-sparing surgery in eight patients. J Clin Endocrinol Metab. 2007:92(2):612-5.

3. BarwickTD, Malhotra A, Webb JA, Savage MO, Reznek RH. Embryology of the adrenal glands and its relevance to diagnostic imaging. Clin Radiol. 2005;60(9):953-9.

4. Cabrera MS, Vogiatzi MG, New MI. Long term outcome in adult males with classic congenital adrenal hyperplasia. J Clin Endocrinol Metab. 2001;86(7):3070-8

5. Stikkelbroeck NM, Otten BJ, Pasic A, et al. High prevalence of testicular adrenal rest tumors, impaired spermatogenesis, and Leydig cell failure in adolescent and adult males with congenital adrenal hyperplasia. J Clin Endocrinol Metab. 2001;86(12):5721-8.

6. Stikkelbroeck NM, Hermus AR, Suliman HM, Jager GJ, Otten BJ. Asymptomatic testicular adrenal rest tumours in adolescent and adult males with congenital adrenal hyperplasia: basal and follow-up investigation after 2.6 years. J Pediatr Endocrinol Metab. 2004;17(4):645-53

7. Urban MD, Lee PA, Migeon CJ. Adult height and fertility in men with congenital virilizing adrenal hyperplasia. $N$ Engl J Med. 1978;299(25):1392-6.

8. Willi U, Atares M, Prader A, Zachmann M. Testicular adrenal-like tissue (TALT) in congenital adrenal hyperplasia: detection by ultrasonography. Pediatr Radiol. 1991;21(4):284-7

9. Vanzulli A, DelMaschio A, Paesano P, et al. Testicular masses in association with adrenogenital syndrome: US findings. Radiology. 1992;183(2):425-9

10. Avila NA, Premkumar A, Shawker TH, et al. Testicular adrenal rest tissue in congenital adrenal hyperplasia: findings at Gray-scale and color Doppler US. Radiology. 1996;198(1):99-104.

11. Wilkins L, Fleishmann W, Howard JE. Macrogenitosomia precox associated with hyperplasia of the androgenic tissue of the adrenal and death from corticoadrenal insufficiency case report. Endocrinology. 1940;26(3):385-95. Available from: http://endo.endojournals.org/cgi/ content/abstract/26/3/385. Accessed in 2011 (Feb 21).

12. Rich MA, Keating MA. Leydig cell tumors and tumors associated with congenital adrenal hyperplasia. Urol Clin North Am. 2000;27(3):519-28, x.

13. Knudsen JL, Savage A, Mobb GE. The testicular'tumor' of adrenogenital syndrome--a persistent diagnostic pitfall. Histopathology. $1991 ; 19(5): 468-70$
14. Kim I, Young RH, Scully RE. Leydig cell tumors of the testis. A clinicopathological analysis of 40 cases and review of the literature. Am J Surg Pathol. 1985;9(3):177-92.

15. Witchel SF, Nayak S, Suda-Hartman M, Lee PA. Newborn screening for 21-hydroxylase deficiency: results of CYP21 molecular genetic analysis. J Pediatr. 1997;131(2):328-31.

16. Allen DB, Hoffman GL, Fitzpatrick P, et al. Improved precision of newborn screening for congenital adrenal hyperplasia using weight-adjusted criteria for 17-hydroxyprogesterone levels. J Pediatr. 1997;130(1):128-33.

17. Gruñeiro-Papendieck L, Prieto L, Chiesa A, et al. Neonatal screening program for congenital adrenal hyperplasia: adjustments to the recall protocol. Horm Res. 2001;55(6):271-7.

18. Merke DP, Bornstein SR. Congenital adrenal hyperplasia. Lancet. 2005;365(9477):2125-36

19. Joint LWPES/ESPE CAH Working Group. Consensus statement on 21 hydroxylase deficiency from the Lawson Wilkins Pediatric Endocrine Society and the European Society for Paediatric Endocrinology. J Clin Endocrinol Metab. 2002;87(9):4048-53.

20. Speiser PW. Congenital adrenal hyperplasia owing to 21-hydroxylase deficiency. Endocrinol Metab Clin North Am. 2001;30(1):31-59, vi.

21. Mesino S, Jaffe RB. Developmental and functional biology of the primate fetal adrenal cortex. Endocr Rev. 1997;18(3):378-403.

22. Fujieda K, Tajima T. Molecular basis of adrenal insufficiency. Pediatr Res. 2005;57(5 Pt 2):62R-69R.

23. Graham LS. Celiac accessory adrenal glands. Cancer. 1953;6:149-52. Available from: http://onlinelibrary.wiley.com/doi/10.1002/10970142(195301)6:1\%3C149::AID-CNCR2820060115\%3E3.0.CO;2-8/pdf. Accessed in 2011 (Feb 21)

24. Falls $J$. Accessory adrenal cortex in the broad ligament: incidence and functional significance. Cancer. 1955;8(1):143-50.

25. Dahl EV, Bahn RC. Aberrant adrenal contical tissue near the testis in human infants. Am J Pathol. 1962:40:587-98.

26. Symonds DA, Driscoll SG. An adrenal cortical rest within the fetal ovary: report of a case. Am J Clin Pathol. 1973;60(4):562-4

27. Rutgers $U$, Young RH, Scully RE. The testicular "tumor" of the adrenogenital syndrome. A report of six cases and review of the literature on testicular masses in patients with adrenocortical disorders. Am J Surg Pathol. 1988;12(7):503-13.

28. Cutfield RG, Bateman JM, Odell WD. Infertility caused by bilatera testicular masses secondary to congenital adrenal hyperplasia (21hydroxylase deficiency). Fertil Steril. 1983;40(6):809-14.

29. Cunnah D, Perry L, Dacie JA, et al. Bilateral testicular tumours in congenital adrenal hyperplasia: a continuing diagnostic and therapeutic dilemma. Clin Endocrinol (Oxf). 1989;30(2):141-7.

30. Blumberg-Tick J, Boudou P, Nahoul K, Schaison G. Testicular tumors in congenital adrenal hyperplasia: steroid measurements from adrenal and spermatic veins. J Clin Endocrinol Metab. 1991;73(5):1129-33.

31. Combes-Moukhovsky ME, Kottler ML, Valensi P, et al. Gonadal and adrenal catheterization during adrenal suppression and gonadal 
stimulation in a patient with bilateral testicular tumors and congenital adrenal hyperplasia. J Clin Endocrinol Metab. 1994;79(5):1390-4.

32. Srikanth MS, West BR, Ishitani $M$, et al. Benign testicular tumors in children with congenital adrenal hyperplasia. J Pediatr Surg. 1992;27(5):639-41.

33. Clark RV, Albertson BD, Munabi A, et al. Steroidogenic enzyme activities, morphology, and receptor studies of a testicular adrenal rest in a patient with congenital adrenal hyperplasia. J Clin Endocrinol Metab. 1990;70(5):1408-13.

34. Moore GW, Lacroix A, Rabin D, McKenna TJ. Gonadal dysfunction in adult men with congenital adrenal hyperplasia. Acta Endocrinol (Copenh). 1980;95(2):185-93.

35. Radfar N, Bartter FC, Easley R, et al. Evidence for endogenous LH suppression in a man with bilateral testicular tumors and congenital adrenal hyperplasia. J Clin Endocrinol Metab. 1977;45(6):1194-204.

36. Avila NA, ShawkerTS, Jones JV, Cutler GB Jr, Merke DP. Testicular adrenal rest tissue in congenital adrenal hyperplasia: serial sonographic and clinical findings. AJR Am J Roentgenol. 1999;172(5):1235-8.

37. Peggy $P$, Francois $D$, Francois $T$, et al. Adrenal rest tissue in gonads in 70 French patients with classical congenital adrenal hyperplasia (21 hydroxylase deficiency). European Congress of Endocrinology; 2007. Budapest, Hungary, 28 April - 02 May 2007. Endocrine Abstracts. 2007;14:P632. Available from: http://www.endocrine-abstracts.org/ ea/0014/ea0014p632.htm. Accessed in 2011 (Feb 21).

38. Jensen TK, Andersson AM, Hjollund NH, et al. Inhibin B as a serum marker of spermatogenesis: correlation to differences in sperm concentration and follicle-stimulating hormone levels. A study of 349 Danish men. J Clin Endocrinol Metab. 1997;82(12):4059-63.

39. Anawalt BD, Bebb RA, Matsumoto AM, et al. Serum inhibin B levels reflect Sertoli cell function in normal men and men with testicular dysfunction. J Clin Endocrinol Metab. 1996;81(9):3341-5.

40. Andersson AM, Petersen JH, Jørgensen N, Jensen TK, Skakkebaek NE. Serum inhibin B and follicle-stimulating hormone levels as tools in the evaluation of infertile men: significance of adequate reference values from proven fertile men. J Clin Endocrinol Metab. 2004;89(6):2873-9.

41. Lee MM, Donahoe PK, Silverman BL, et al. Measurements of serum müllerian inhibiting substance in the evaluation of children with nonpalpable gonads. N Engl J Med. 1997;336(21):1480-6.

42. Martinez-Aguayo A, Rocha A, Rojas N, et al. Testicular adrenal rest tumors and Leydig and Sertoli cell function in boys with classical congenital adrenal hyperplasia. J Clin Endocrin Metab. 2007;92(12):4583-9.

43. Claahsen-van der Grinten HL, Otten BJ, Sweep FC, et al. Testicular tumors in patients with congenital adrenal hyperplasia due to 21hydroxylase deficiency show functional features of adrenocortical tissue. J Clin Endocrinol Metab. 2007;92(9):3674-80.

44. Stikkelbroeck NM, Hoefsloot LH, de Wijs IJ, et al. CYP21 gene mutation analysis in 198 patients with 21-hydroxylase deficiency in The Netherlands: six novel mutations and a specific cluster of four mutations. J Clin Endocrinol Metab. 2003;88(8):3852-9.
45. Walker BR, Skoog SJ, Winslow BH, Canning DA, Tank ES. Testis sparing surgery for steroid unresponsive testicular tumors of the adrenogenital syndrome. J Urol. 1997;157(4):1460-3.

46. Bonaccorsi AC, Adler I, Figueiredo JG. Male infertility due to congenital adrenal hyperplasia: testicular biopsy findings, hormonal evaluation, and therapeutic results in three patients. Fertil Steril. 1987;47(4):664-70.

47. Augarten A, Weissenberg R, Pariente C, Sack J. Reversible male infertility in late onset congenital adrenal hyperplasia. J Endocrinol Invest. 1991;14(3):237-40.

48. New MI, Wilson RC. Steroid disorders in children: congenital adrenal hyperplasia and apparent mineralocorticoid excess. Proc Natl Acad Sci U S A. 1999;96(22):12790-7.

49. Murphy H, George C, de Kretser D, Judd S. Successful treatment with ICSI of infertility caused by azoospermia associated with adrenal rests in the testes: case report. Hum Reprod. 2001;16(2):263-7.

50. Sugino Y, Usui T, Okubo K, et al. Genotyping of congenital adrenal hyperplasia due to 21-hydroxylase deficiency presenting as male infertility: case report and literature review. J Assist Reprod Genet. 2006;23(9-10):377-80

51. Kalachanis I, Rousso D, Kourtis A, et al. Reversible infertility, pharmaceutical and spontaneous, in a male with late onset congenital adrenal hyperplasia, due to 21-hydroxylase deficiency. Arch Androl. 2002;48(1):37-41.

52. Iwamoto T, Yajima M, Tanaka H, Minagawa N, Osada T. [A case report: reversible male infertility due to congenital adrenal hyperplasia]. Nippon Hinyokika Gakkai Zasshi. 1993;84(11):2031-4.

53. Yang RM, Fefferman RA, Shapiro CE. Reversible infertility in a man with 21-hydroxylase deficiency congenital adrenal hyperplasia. Fertil Steril. 2005;83(1):223-5.

54. Fernandes VO, Barros Al, Quidute AR, et al. Tumores testiculares bilaterais por hiperplasia congênita de restos adrenais [Bilateral testicular tumors caused by congenital adrenal rest hyperplasia]. Arq Bras Endocrinol Metabol. 2009;53(8):1052-8.

Place where the paper was presented: $30^{\text {th }}$ Congress of the Société Internationale d'Urologie, Shanghai, 2009

Sources of funding: None

Conflict of interest: None

Date of first submission: August 3, 2010

Last received: March 10, 2011

Accepted: March 16, 2011

\section{Address for correspondence:}

Giovanni Scala Marchini

Alameda Joaquim Eugênio de Lima, 177 — apto 151

Jardim Paulista — São Paulo (SP) — Brasil

CEP 01403-001

Tel. (+55 11) 3965-6135

Cel. (+55 11) 8179-8186

E-mail: gsmarchini@hotmail.com 